\title{
EDIBLE COATING MINYAK ATSIRI KEMANGI (OCIMUM BASILICUM) PADA FILLET IKAN NILA (OREOCHROMIS NILOTICUS) SELAMA PENYIMPANAN DINGIN
}

\section{Basil Essential Oil (Ocimum basilicum) Edible Coating in Tilapia Fillet (Oreochromis niloticus) During Cold Storage}

\author{
Selly Fidia Agustin, Ardhea Mustika Sari, Lia Umi Khasanah \\ Program Studi Ilmu Teknologi Pangan - Fakultas Pertanian - Universitas Sebelas Maret \\ Jl. Ir. Sutami No. 36 A, Pucangsawit, Kec. Jebres - Kota Surakarta 57126 \\ *Penulis Korespondensi, email: ardhea_ms@staff.uns.ac.id
}

Disubmit: 3 Agustus 2020 Direvisi: 23 Oktober 2020 Diterima: 8 Desember 2020

\begin{abstract}
ABSTRAK
Fillet merupakan produk perikanan yang mudah mengalami kerusakan. Tujuan dari penelitian ini adalah mengetahui karakteristik minyak atsiri kemangi, dan edible film alginat dengan penambahan minyak atsiri kemangi, serta kemunduran mutu fillet ikan nila dengan aplikasi edible coating minyak atsiri kemangi selama penyimpanan dingin. Penelitian ini menggunakan Rancangan Acak Lengkap dengan satu faktor yaitu konsentrasi minyak atsiri kemangi $0,5 \%, 1 \%$, dan 1,5\% pada suhu $4{ }^{\circ} \mathrm{C}$. Data yang diperoleh dianalisis menggunakan one way ANOVA dan dilanjutkan dengan DMRT pada a 0,05 serta paired $t$-test pada a 0,05 . Berdasarkan hasil karakterisasi minyak atsiri kemangi dapat diketahui rendemen minyak atsiri kemangi sebesar $0,4 \%$, berat jenis $0,853 \mathrm{~g} / \mathrm{cm}^{3}$, viskositas 0,002 N.m/s $\mathrm{s}^{2}$ dan terdapat 38 senyawa aktif. Minyak atsiri kemangi memiliki diameter hambat bakteri Pseudomonas aeruginosa antara 5,667-18.350 mm. Edible film natrium alginat dengan penambahan minyak atsiri kemangi 0,5\%, 1\%, dan 1,5\% memiliki nilai Water Vapor Transmission Rate (WVTR) sebesar 4,385-5,254 g/jam m², kuat tarik 2,718-2,788 MPa, dan ketebalan 0,05-0,105 mm. Edible coating dilakukan dengan penambahan minyak atsiri kemangi $0 \%$ dan $1,5 \%$. Coating fillet ikan nila dilakukan dengan metode dipping selama 1-2 menit. Hasil penelitian menunjukkan penggunaan edible coating minyak atsiri kemangi berpengaruh nyata terhadap parameter TPC, TVB, dan TBA, akan tetapi tidak berpengaruh nyata terhadap $\mathrm{pH}$
\end{abstract}

Kata kunci : Edible Coating; Kemangi; Minyak Atsiri; Penyimpanan Dingin

\begin{abstract}
The fillet is a perishable fishery product. This research aimed to determine the characteristics of basil essential oil (EO) and sodium alginate (SA) edible film with the addition of basil EO, and deterioration of tilapia fillet with the application of basil EO edible coating during cold storage. Complete Randomized Design with one factor, concentration of basil EO $0,5 \%, 1 \%$, and $1,5 \%$ stored in $4{ }^{\circ} \mathrm{C}$ was used in this study. The data obtained were analyzed using one way ANOVA and continued with DMRT and paired t-test at $a=0,05$. Based on the characterization of basil EO, the yield of basil EO was 0,4\%, specific gravimetry was $0,853 \mathrm{~g} /$ $\mathrm{m}^{3}$, viscosity was $0,002 \mathrm{N.m} / \mathrm{s}^{2}$, and contained 38 active compounds. Basil EO has inhibitory diameters of Pseudomonas aeruginosa between 5,667-18,350 mm. SA edible film with the addition of 0,5\%, 1\%, and 1,5\% basil EO has a WVTR value of 4,385-5,254 g/hour $\mathrm{m}^{2}$, tensile strength of 2,718-2,788 MPa, and thickness of 0,05-0,105 mm. Application of edible coating to tilapia fillet was carry on by adding 1,5\% basil $E O$ and without adding basil $E O$ as a control. Tilapia fillet coating was done using a dipping method for 1-2 minutes. The result showed the use of basil EO significantly affected the TPC, TVB, and TBA, but didn't significantly affect the $\mathrm{pH}$. The use of edible coating with the addition of 1,5\% basil EO exceeds the acceptable limit on the $9^{\text {th }}$ day storage meanwhile the control treatment has exceeded the acceptable limit on the $6^{\text {th }}$ day storage based on TVB value
\end{abstract}

Keywords : Microbiological damage; Oxidative Damage, Sodium Alginate 


\section{PENDAHULUAN}

Ikan nila (Oreochromis niloticus) merupakan ikan yang memiliki nilai gizi yang tinggi sehingga tepat sebagai sumber protein hewani yang murah dan mudah didapat. Selain itu, ikan nila juga termasuk komoditas yang banyak diminati oleh konsumen baik di pasar lokal maupun ekspor. Berdasarkan data Kementerian Kelautan dan Perikanan (2018), jumlah produksi ikan nila di Indonesia pada tahun 2017 sebesar 69,67 ton dan berdasarkan data Balai Karantina Ikan, Pengendalian Mutu, dan Keamanan Hasil Perikanan (BKIPM) Kementerian Kelautan dan Perikanan, jumlah ekspor fillet ikan nila pada tahun 2017 berjumlah 8.649,42 ton dengan negara tujuan Amerika, Jepang, dan Eropa. Secara umum, terdapat dua jenis ikan nila yang di budidayakan di Indonesia, yaitu ikan nila berwarna hitam (BEST) dan ikan nila berwarna merah (NIFI). Pada penelitian ini digunakan ikan nila berwarna hitam. Hal tersebut dikarenakan ikan nila hitam lebih mudah dibudidayakan dibanding ikan nila merah dan rasa yang lebih enak (Gustiano et al., 2008).

Fillet ikan nila memiliki kelemahan diantaranya tidak dapat mempertahankan kesegarannya dalam waktu yang lama dikarenakan pada proses pembuatan fillet telah merusak pertahanan alaminya (Husni dan Putra, 2018). Kerusakan fillet ikan umumnya terjadi karena aktivitas enzim (autolisis), kontaminasi bakteri, dan oksidasi (Apriani et al., 2013). Upaya mencegah kerusakan dan memperpanjang umur simpan dari fillet ikan nila, perlu dilakukan beberapa upaya pengawetan. Upaya Pengawetan mampu mempertahankan kesegaran ikan dengan cara menghambat penyebab kemunduran mutu. Pada proses pengawetan dikenal istilah hurdle concept, yaitu treatment pengawetan pangan dengan mengkombinasikan beberapa metode pengawetan. Teknologi ini dapat dilakukan dengan memanipulasi beberapa faktor seperti suhu penyimpanan, pengemasan, penggunaan senyawa antimikroba, dan antioksidan (Nura et al., 2016).

Pengawetan pada suhu dingin adalah proses pengawetan pangan menggunakan suhu penyimpanan berkisar antara $(-2)-10{ }^{\circ} \mathrm{C}$ (Sahubawa dan Ustadi, 2014). Berdasarkan Sipayung et al., (2015), fillet ikan nila yang disimpan pada suhu $5^{\circ} \mathrm{C}$ secara organoleptik hanya bertahan sampai hari keempat. Pengawetan fillet ikan dapat pula dilakukan dengan mengkombinasikan penyimpanan pada suhu ren- dah dan penggunaan pengemas. Penggunaan pengemas berperan dalam melindungi produk dari kerusakan fisik, kimiawi, dan biologis sehingga mampu memperpanjang umur simpan produk (Parreidt et al., 2018). Edible coating dapat juga digunakan sebagai alternatif pengganti plastik karena bersifat biodegradable sekaligus barrier untuk mengendalikan transfer uap air, oksigen dan lipid (Rosida et al., 2018).

Penelitian Lu et al. (2009) menunjukkan edible coating alginat pada ikan nothern snakehead yang disimpan pada suhu $4 \pm 1{ }^{\circ} \mathrm{C}$ secara sensoris mampu bertahan sampai hari ke-5. Upaya meningkatkan kemampuan edible coating dalam menghambat kerusakan fillet ikan nila, dapat ditambahkan minyak atsiri kemangi (Ocimum basilicum).

Minyak atsiri kemangi mengandung senyawa fenolik dan linalool yang berperan sebagai antioksidan (Al-Maskri et al., 2011) dan senyawa golongan terpena yang berperan sebagai antimikroba (Swamy et al., 2016). Terdapat beberapa penelitian mengenai aplikasi edible coating dengan penambahan minyak atsiri pada produk perikanan yang disimpan pada suhu dingin. Penelitian Shabanpour et al. (2013), menunjukkan edible coating kitosan dengan penambahan minyak atsiri thyme $1 \%$ mampu memperpanjang umur simpan fillet ikan rainbow trout sampai 14 hari penyimpanan pada suhu refrigerator.

Aplikasi edible coating dengan penambahan minyak atsiri oregano (Vital et al., 2018), minyak atsiri jahe merah dan minyak atsiri lengkuas merah mampu meningkatkan umur simpan fillet ikan serta menghambat beberapa kerusakan mikrobiologis dengan cara menghambat pertumbuhan bakteri pathogen (Utami et al., 2013). Namun, penelitian mengenai aplikasi edible coating dengan penambahan minyak atsiri kemangi belum pernah dilaporkan. Oleh karena itu, perlu dilakukan penelitian untuk mengetahui adanya pengaruh penggunaan edible coating natrium alginat dengan penambahan minyak atsiri kemangi untuk menghambat kerusakan mikrobiologis dan oksidatif pada fillet ikan nila yang disimpan pada suhu dingin.

\section{METODE}

Alat yang digunakan dalam destilasi minyak atsiri kemangi adalah pisau, neraca, dan satu set alat destilasi uap air. Alat yang digunakan pada pembuatan edible film dan 
aplikasi edible coating minyak atsiri kemangi pada fillet nila antara lain neraca analitik (ohaus AR 2140), gelas beaker (Pyrex), magnetic stirrer, hot plate, termometer, loyang, gelas ukur (Pyrex), propipet, pipet volume (Pyrex), cabinet dryer, alat pengering termodifikasi, talenan, pisau, sealer, dan refrigerator.

Peralatan yang digunakan untuk analisis sampel adalah neraca analitik (ohaus AR 2140), gelas ukur (Pyrex), piknometer, viscometer ostwald, GC-MS Agilent (seri GC 6890, MS 5973), alumunium foil, autoclave, erlenmeyer (Pyrex), cawan petri, labu takar (Pyrex), laminar air flow, pipet tetes, mikropipet, jarum ose, tabung reaksi, vortex, botol timbang, jangka sorong, micrometer (Krisbow), oven (memmert type UNB 400), universal tensile strength tester, gelas beaker (Pyrex), pH meter, kertas saring no 2-3, corong, cawan Conway, buret, alat destilasi, dan spektrofotometer.

Bahan utama yang digunakan pada penelitian ini adalah kemangi umur 2-3 bulan yang diperoleh dari Desa Tegalgiri, Kecamatan Nogosari, Boyolali dan ikan nila hitam umur 4-6 bulan yang diperoleh dari tambak "Agung Ikan" di Desa Karangpandan, Karanganyar. Bahan yang digunakan untuk pembuatan edible film dan aplikasi edible coating minyak atsiri kemangi pada fillet ikan nila adalah natrium alginat food grade, $\mathrm{CaCl}_{2^{\prime}}$ gliserol, dan aquades. Bahan yang digunakan untuk analisis sampel antara lain aquades, gas nitrogen, media nutrient agar (Merck), larutan garam fisiologis, tween 20, kultur murni Pseudomonas aeruginosa FNCC63, media plate count agar (Merck), indikator methyl red 0,1\%, indikator bromthymol blue 0,1\%, larutan trichloroacetic acid 7,5\%, asam borat $1 \%$, kalium karbonat, $\mathrm{HCl} 0,02 \mathrm{~N}$, vaselin, $\mathrm{HCl} 4 \mathrm{M}$. dan pereaksi thiobarbituric acid (TBA).

\section{Tahapan Penelitian}

\section{Destilasi dan Karakterisasi Minyak Atsiri Kemangi}

Kemangi dikeringkan menggunakan metode kering angin, dengan cara dihamparkan pada suhu ruang $\pm 25^{\circ} \mathrm{C}$ selama 7 hari kemudian dipotong 3-4 cm. Destilasi minyak atsiri kemangi dilakukan dengan metode destilasi uap air. Sebanyak 10 liter air dimasukkan dalam tangki destilasi di bawah angsang, kemudian kemangi dimasukkan dalam tangki destilasi dengan kapasitas $2 \mathrm{~kg}$ bahan kering. Destilasi dilakukan selama 5 jam. Minyak atsiri yang dihasilkan kemudian dilakukan karakterisasi meliputi rendemen, berat jenis, viskositas, senyawa aktif, dan aktivitas antimikroba.

\section{Pembuatan dan Karakterisasi Edible Film Minyak Atsiri Kemangi}

Sebanyak 0,05 g $\mathrm{CaCl}_{2}$ dilarutkan dalam $100 \mathrm{ml}$ aquades yang telah dipanaskan hingga suhu $65^{\circ} \mathrm{C}$ kemudian ditambahkan 2,5 g natrium alginat dan diaduk sampai homogen menggunakan hot plate dengan kecepatan $400 \mathrm{rpm}$. Ditambahkan $2 \mathrm{ml}$ gliserol dan diaduk sampai homogen selama 10 menit. Larutan yang telah homogen didinginkan sampai suhu $45^{\circ} \mathrm{C}$ lalu ditambahkan minyak atsiri kemangi dengan konsentrasi $0,5 \%, 1 \%$, dan 1,5\%. Larutan diaduk sampai homogen selama 20-30 menit atau sampai minyak atsiri kemangi tidak berada di bagian permukaan larutan. Larutan edible film dicetak pada loyang berukuran $18,5 \times 27,5 \mathrm{~cm}$ dan dikeringkan menggunakan cabinet dryer dengan suhu $60^{\circ} \mathrm{C}$ selama 20 jam. Edible film yang dihasilkan kemudian dilakukan karakterisasi meliputi ketebalan, WVTR, dan kuat tarik.

\section{Penentuan Konsentrasi Minyak Atsiri Terpilih}

Pemilihan konsentrasi minyak atsiri kemangi yang menghasilkan edible film dengan karakteristik yang baik dari segi ketebalan, WVTR, kuat tarik, dan aktivitas antimikroba. Konsentrasi terpilih pada tahap ini akan diaplikasikan pada tahap aplikasi edible coating pada fillet ikan nila.

\section{Aplikasi Edible Coating Minyak Atsiri Kemangi Pada Fillet Ikan Nila}

Fillet ikan nila yang digunakan adalah ikan dengan berat $100 \mathrm{~g}$ dengan panjang 15-16 cm, lebar $\pm 8 \mathrm{~cm}$, dan ketebalan 1-3 $\mathrm{cm}$. Fillet ikan nila kemudian dicelupkan dalam larutan edible coating kontrol dan larutan edible coating dengan konsentrasi terpilih dalam kondisi hangat $\left(50{ }^{\circ} \mathrm{C}\right)$ selama 1-2 menit. Fillet kemudian dikeringkan selama 20 menit dan dikemas menggunakan plastik polyprophylene. Fillet disimpan pada refrigerator dengan suhu $4{ }^{\circ} \mathrm{C}$ selama 12 hari. Analisis untuk mengetahui kerusakan fillet ikan nila dilakukan yaitu analisis thiobarbituric acid (TBA), total plate count (TPC), total volatile base (TVB), dan $\mathrm{pH}$ pada hari ke-0, 3, 6, 9, dan 12. 


\section{Analisis Data}

Penelitian ini menggunakan Rancangan Acak Lengkap (RAL) satu faktor yaitu konsentrasi minyak atsiri kemangi. Data yang diperoleh dianalisis dengan SPSS menggunakan one way ANOVA. Apabila hasil pengukuran menunjukkan terdapat perbedaan nyata antar perlakuan, maka dilanjutkan dengan Duncan's Multiple Range Test (DMRT) pada taraf signifikansi 0,05. Untuk mengetahui pengaruh konsentrasi minyak atsiri kemangi terhadap karakteristik fillet ikan nila, data yang diperoleh dianalisis menggunakan paired t-test dengan taraf signifikansi 0,05.

\section{HASIL DAN PEMBAHASAN}

\section{Karakterisasi Minyak Atsiri Kemangi Hasil Destilasi}

Minyak atsiri kemangi diperoleh dengan cara destilasi menggunakan alat destilasi uap air. Perlakuan pendahuluan dilakukan sebelum proses destilasi yaitu pengeringan dan pengecilan ukuran. Hal ini dikarenakan kemangi memiliki kadar air yang cukup tinggi serta ukuran yang tidak seragam sehingga membutuhkan waktu destilasi yang cukup panjang. Adapun parameter yang diamati pada proses karakterisasi diantara rendemen, berat jenis, pengujian viskositas yang terdapat pada Tabel 1 , serta pengujian kandungan senyawa aktif yang terdapat pada Gambar 1.

\section{Rendemen Minyak Atsiri Kemangi}

Destilasi minyak atsiri kemangi dilakukan sebanyak tiga kali, dengan rata-rata rendemen $0,40 \%$ (Tabel 1). Hasil tersebut lebih tinggi dari rendemen minyak atsiri yang berasal dari kemangi segar dengan metode destilasi air pada penelitian Ladwani et al. (2018) yaitu sebesar $0,13-0,37 \%$, namun lebih rendah dari minyak atsiri dengan metode destilasi uap pada penelitian Mindaryani dan Rahayu (2007), dengan rendemen sebesar 0,5736-0,66\%. Asal bahan baku, perlakuan pendahuluan, dan metode destilasi diduga berpengaruh terhadap rendemen minyak atsiri.

Metode pengeringan, ukuran bahan yang digunakan berpengaruh terhadap rendemen minyak atsiri. Pengeringan dengan metode kering angin akan menghasilkan rendemen minyak atsiri yang lebih tinggi dibandingkan pengeringan di bawah matahari dan pengeringan oven $60{ }^{\circ} \mathrm{C}$. Penggunaan suhu yang terlalu tinggi menyebabkan kehilangan minyak atsiri yang besar karena adanya proses penguapan (Hassanpouraghdam et al., 2010). Pemotongan bertujuan untuk menambah luas permukaan sehingga kelenjar minyak dapat terbuka sebanyak mungkin dan permukaan bahan yang kontak dengan uap panas semakin besar (Nugraheni et al., 2016). Pemilihan ukuran bahan harus dilakukan dengan tepat. Ukuran bahan yang terlalu kecil dapat menyebabkan kandungan minyak atsiri menguap akibat sel-sel daun yang menyimpan minyak atsiri hancur. Selain itu, gesekan antara bahan dengan alat perajang akan menimbulkan panas yang diduga menyebabkan kandungan minyak atsiri yang bersifat volatil menguap (Khasanah et al., 2015).

Pada penelitian ini, sebelum dikering anginkan, dilakukan pengecilan ukuran kemangi agar seragam dengan cara dirajang dengan ukuran sepanjang 3-4 cm (Chakraborty dan Dey, 2016). Hal ini dilakukan sebagai upaya optimasi rendeman minyak atsiri yang terkandung di dalam kemangi.

Selain itu, pada penelitian ini digunakan metode destilasi uap air. Penggunaan media air dikarenakan bahan merupakan bahan pangan sehingga aman untuk dikonsumsi. Destilasi uap air memiliki suhu proses yang lebih tinggi dibandingkan metode destilasi air. Destilasi uap air mampu menghasilkan uap dan panas yang konstan sehingga waktu destilasi yang dibutuhkan singkat dan meminimalisir kemungkinan kerusakan minyak atsiri (Nugraheni et al., 2016).

\section{Senyawa Aktif}

Pengujian senyawa aktif dengan menggunakan analisis Gas Kromatografi. Pada pengujian tersebut terdapat 38 senyawa yang dapat diidentifikasi pada minyak atsiri kemangi pada penelitian ini (Gambar 1). Menurut Swamy et al. (2016), minyak atsiri tersusun dari senyawa terpena, dan senyawa aromatik lain. Komponen utama pada minyak atsiri kemangi terdiri dari komponen dengan presentase lebih dari 5\%, diantaranya Linalool L $(5,71 \%)$, z-citral $(21,78 \%)$, citral $(29,12 \%)$, trans-caryophyllene $(6,33 \%)$, dan cis-a-bisabolene $(9,96 \%)$ (Pujiarti et al., 2015). Penelitian Chenni et al. (2016), komponen utama minyak atsiri kemangi diantaranya linalool, camphor, methyl cavicol, methyl cinnamate, 
Tabel 1. Hasil karakterisasi minyak atsiri kemangi

\begin{tabular}{lccl}
\hline Parameter & Satuan & Hasil Penelitian & Referensi \\
\hline Rendemen & $\%$ & 0,400 & $0,13-0,37^{\mathrm{a}} ; 0,574-0,66^{\mathrm{b}}$ \\
Berat Jenis & $\mathrm{g} / \mathrm{ml}$ & 0,853 & $0,860-0,95^{\mathrm{c}} ; 0,869^{\mathrm{d}}$ \\
Viskositas & $\mathrm{N} . \mathrm{s} / \mathrm{m}^{2}$ & 0,002 & - \\
\hline
\end{tabular}

Keterangan: a. Ladwani et al. (2018); b. Mindaryani dan Rahayu, (2007); c. Srivastava et al. (2014); d. Fajarini dan Murrukmihadi, (2015)

Tabel 2. Aktivitas antimikroba minyak atsiri kemangi

\begin{tabular}{lcc}
\hline Sampel & Diameter Hambat $(\mathbf{m m})$ & $\begin{array}{c}\text { Kategori } \\
\text { (Elgayyar } \text { et al., 2001) }\end{array}$ \\
\hline Konsentrasi 0,5\% & $5,667^{\mathrm{a}} \pm 0,3786$ & Tidak menghambat \\
Konsentrasi 1\% & $7,250^{\mathrm{a}} \pm 0,4924$ & Tidak menghambat \\
Konsentrasi 1,5\% & $18,350^{\mathrm{b}} \pm 2,1160$ & Sedang \\
\hline Keterangan: notasi yang sama pada kolom yang sama menunjukkan tidak ada perbedaan nyata pada a 0,5
\end{tabular}

Tabel 3. Matriks penentuan konsentrasi terbaik edible coating berbasis natrium alginat-minyak atsiri kemangi berdasarkan karakteristik edible film

\begin{tabular}{lccc}
\hline \multirow{2}{*}{ Parameter } & \multicolumn{3}{c}{ Konsentrasi minyak atsiri kemangi } \\
\cline { 2 - 4 } & $0,5 \%$ & $1 \%$ & $1,5 \%$ \\
\hline Ketebalan $(\mathrm{mm})$ & $0,050^{\mathrm{a}} \pm 0,0030$ & $0,093^{\mathrm{b}} \pm 0,0035$ & $0,105^{\mathrm{c}} \pm 0,0023$ \\
WVTR $\left(\mathrm{g} / \mathrm{jam} \cdot \mathrm{m}^{2}\right)$ & $5,254^{\mathrm{b}} \pm 0,4994$ & $4,830^{\mathrm{ab}} \pm 0,2103$ & $4,385^{\mathrm{a}} \pm 0,4212$ \\
Kuat tarik $(\mathrm{Mpa})$ & $2,720^{\mathrm{a}} \pm 0,2139$ & $2,718^{\mathrm{a}} \pm 0,7518$ & $2,788^{\mathrm{a}} \pm 0,7046$ \\
\hline Keterangan: notasi yang sama pada kolom yang sama menunjukkan tidak ada perbedaan nyata pada $\alpha 0,05$
\end{tabular}

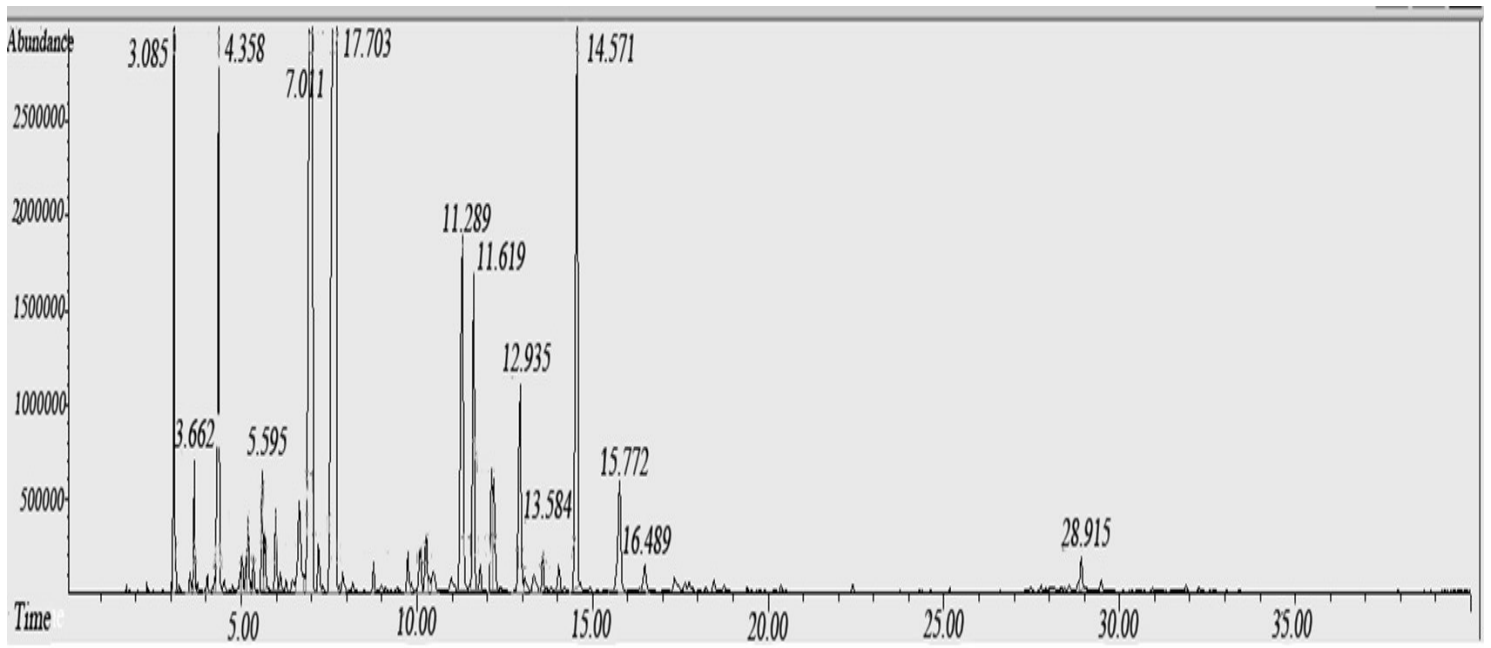

Gambar 1. Kromatogram GC-MS minyak atsiri kemangi (Ocimum basilicum) 
dan eugenol. Pada penelitian Politeo et al. (2007), komponen utama pada minyak atsiri kemangi antara lain linalool, estragole, (E)methyl cinnamate, eugenol, dan a-cadinol.

Pada penelitian ini, terdapat kandungan Linanool sebesar 5,71\%. Menurut penelitian Widati et al. (2006), Linalool diketahui memiliki aktivitas antimikroba yang tinggi. Linalool mampu melisiskan membran sel sehingga mampu menghambat laju pertumbuhan sel mikroba. Berdasarkan penelitian Lingga et al. (2016), linalool mampu menghambat pertumbuhan bakteri gram positif maupun negatif seperti B. subtilis, S. aureus, E. coli, dan Candida utilitis. Citral (3,7-dimethyl-2-6-octadienal) merupakan senyawa aldehida monoterpena yang terdiri dari dua isomer geometrik, yaitu E-citral atau dikenal dengan geranial dan Zcitral yang lebih dikenal dengan neral. Adanya citral dapat menunjukkan efek penghambatan terhadap bakteri gram positif dan gram negatif (Linde et al., 2010).

Kandungan yang lain yang terdapat dalam minyak atsiri adalah Trans-carryophyllene yang memiliki aktivitas antimikroba, antioksidan, antikarsinogenik, dan anti-inflamasi. Autooksidasi dapat merubah trans-caryophyllene menjadi caryophyllene oksida yang juga berfungsi sebagai antioksidan (Legault et al., 2013). Kemampuan antimikroba trans-caryophyllene lebih efektif pada bakteri gram positif dibanding bakteri gram negatif (Dahham et al., 2015). Cis-abisabolene merupakan sesquiterpena yang terdapat pada minyak atsiri dan berperan sebagai antioksidan dan antimikroba (Okoh et al., 2011).

\section{Berat Jenis}

Analisa berat jenis pada minyak atsiri kemangi ini dilakukan dengan menggunakan perbandingan dari fraksi ringan dan fraksi berat yang terdapat pada minyak atsiri (Slamet et al., 2019). Tabel 1 menunjukkan berat jenis minyak atsiri kemangi sebesar $0,8535 \mathrm{~g} / \mathrm{ml}$. Beberapa penelitian menunjukkan nilai berat jenis minyak atsiri yang berbeda-beda. Penelitian Srivastava et al. (2014), menyatakan minyak atsiri kemangi yang diperoleh dari India dengan perlakuan bahan segar memiliki nilai berat jenis sebesar $0,860-0,950 \mathrm{~g} / \mathrm{ml}$, sedangkan penelitian Fajarini dan Murrukmihadi (2015), menunjukkan minyak atsiri kemangi dengan perlakuan bahan segar memiliki berat jenis sebesar $0,8694 \mathrm{~g} / \mathrm{ml}$. Berat jenis yang dihasilkan oleh minyak atsiri kemangi pada beberapa penelitian berbeda-beda dikarenakan beberapa faktor seperti asal bahan baku dan pre-treatment yang digunakan.

Berdasarkan Hassanpouraghdam et al. (2010), metode pengeringan yang digunakan berpengaruh terhadap senyawa aktif yang terkandung pada minyak atsiri kemangi, sehingga rasio fraksi ringan dan fraksi berat pada minyak. Beberapa komponen minyak atsiri kemangi seperti trans-a-bergamotene dan trans- $\beta$-farnesene meningkat dengan bertambahnya suhu pengeringan yang digunakan, akan tetapi komponen lain seperti linalool justru mengalami penurunan jumlah. Selain itu pada penelitian ini, minyak atsiri kemangi yang dihasilkan ditemukan memiliki kandungan monoterpena (fraksi ringan) lebih banyak dibanding sesquiterpena sehingga berat jenis akhir pada minyak ini menjadi rendah.

\section{Viskositas}

Analisa viskositas dilakukan dengan menggunakan alat viscometer oswalt. Hasil pengujian nilai viskositas ditunjukkan pada Tabel 1 yaitu sebesar 0,0020 N.s/m². Belum ada penelitian lain yang membahas mengenai viskositas minyak atsiri kemangi. Nilai viskositas berbanding lurus dengan berat jenis minyak atsiri kemangi yang dihasilkan. Nugraheni et al. (2016) melaporkan bahwa terpena merupakan senyawa yang memiliki bobot jenis rendah. Adanya senyawa terpena dalam minyak atsiri kemangi menyebabkan nilai viskositas rendah.

\section{Aktivitas Antimikroba Minyak Atsiri Kemangi Ikan perairan tropis yang disimpan pada suhu dingin umumnya terkontaminasi oleh Pseudomonas. Selain itu, Psychrobacter dan Aeromonas diduga juga turut menyebab- kan pembusukan ikan. Berdasarkan hal tersebut dapat diketahui, mikroba pembusuk utama pada ikan adalah Pseudomonas (Bozi- aris dan Parlapani, 2017). \\ Tabel 2 menunjukkan diameter ham- bat minyak atsiri kemangi terhadap Pseu- domonas aeruginosa. Melalui analisis one way ANOVA $(a=0,05)$ variasi konsentrasi minyak atsiri kemangi memberikan pengaruh nyata terhadap zona hambat pada pertumbuhan Pseudomonas aeruginosa. Diamater zona ham- bat berkisar antara 5,66-18,35 mm. Hasil pen- gujian aktivitas antimikroba minyak atsiri kemangi menunjukkan tidak ada perbedaan}


signifikan antara konsentrasi $0,5 \%$ dan $1 \%$. Namun kedua konsentrasi tersebut berbeda signifikan terhadap konsentrasi 1,5\%.

Berdasarkan Elgayyar et al. (2001), antimikroba dikatakan tidak menghambat apabila memiliki diameter hambat $<12 \mathrm{~mm}$, termasuk kategori hambat rendah apabila memiliki diameter hambat $10-16 \mathrm{~mm}$, kategori sedang memiliki diameter hambat 16-28 $\mathrm{mm}$, dan kategori tinggi memiliki diameter hambat $>28 \mathrm{~mm}$. Penentuan diameter hambat dilakukan dengan mengukur diameter lubang sumuran dan zona bening di sekitar lubang. Berdasarkan Elgayyar et al. (2001), daya hambat minyak atsiri kemangi konsentrasi $0,5 \%$ dan $1 \%$ tidak mampu menghambat pertumbuhan $P$. aeruginosa, sedangkan minyak atsiri kemangi konsentrasi 1,5\% termasuk dalam kategori daya hambat sedang.

Minyak atsiri kemangi yang dihasilkan memiliki beberapa kandungan senyawa terpena yang berperan sebagai antimikroba diantaranya dl-limonene, $\beta$-ocimene, linalool oxide, linalool, cis-epoxy-ocimene, citronellal, nerol, z-citral, citral, geraniol, neryl acetate, copaene, germacrene $\mathrm{D}$, dan $\Delta$-cadinene (Politeo et al., 2007; Linde et al., 2010; AlMaskri et al., 2011; Poonkodi, 2016). Penelitian Mokarizadeh et al. (2017) menyatakan bahwa senyawa terpena menunjukan efek antimikroba karena kemampuannya mengganggu bagian lipid dari membran bilayer bakteri. Selanjutnya, setelah melintasi membran sel bakteri, terpena akan mengganggu daerah utama di dalam sel yang menyebabkan sel bakteri lisis.

\section{Karakterisasi Edible Film Berbasis Natrium Alginat-Minyak Atsiri Kemangi \\ Ketebalan}

Ketebalan merupakan karakteristik penting dalam menentukan kelayakan film sebagai bahan pengemas. Ketebalan mempengaruhi beberapa karakteristik seperti kuat tarik, persen pemanjangan, dan laju transmisi uap air (Arham et al., 2016)

Tabel 3 menunjukkan bahwa penambahan minyak atsiri kemangi dapat meningkatkan ketebalan edible film. Peningkatan konsentrasi minyak atsiri kemangi yang digunakan akan meningkatkan total padatan di dalam edible film setelah dikeringkan sehingga film akan semakin tebal (Kusumawati dan Putri, 2013)

Selain konsentrasi minyak atsiri, secara umum ketebalan edible film juga dipen- garuhi oleh konsentrasi bahan penyusunnya seperti gliserol, natrium alginat, dan luas plat cetakan yang digunakan. Semakin tinggi konsentrasi gliserol dan natrium alginat yang digunakan, maka film yang dihasilkan semakin tebal. Molekul gliserol yang berikatan dengan molekul natrium alginat akan menempati rongga-rongga dalam matriks edible film (Arham et al., 2016). Hal tersebut mampu meningkatkan total padatan dalam larutan film, sehingga pada saat dikeringkan semakin banyak padatan yang mengendap dan film yang terbentuk semakin tebal (Putra et al., 2017).

\section{Water Vapor Transmission Rate (WVTR)}

Film yang digunakan untuk mengemas produk pangan harus memiliki laju transmisi uap air serendah mungkin agar dapat menjaga kualitas dari produk pangan tersebut (Ghanbarzadeh et al., 2011). Tabel 3 menunjukkan nilai WVTR edible film yang dihasilkan berkisar antara 4,385 g/jam m²-5,254 g/jam $\mathrm{m}^{2}$. Hasil ini tidak sesuai dengan standar JIS (1975) dalam Setyaningrum et al. (2017), yang menyatakan bahwa edible film maksimal memiliki nilai water vapor transimission rate sebe-

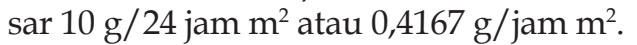

Hasil analisis one way ANOVA dengan nilai a $=0,05$ menunjukkan edible film dengan penambahan minyak atsiri kemangi 0,5\% memiliki nilai WVTR yang berbeda secara signifikan apabila dibandingkan dengan edible film dengan penambahan minyak atsiri 1,5\%. Hasil penelitian ini memiliki pola yang sama dengan penelitian Putra et al. (2017), yang menyatakan bahwa semakin besar konsentrasi minyak atsiri jeruk purut yang ditambahkan pada edible film pati tapioka, maka laju perpindahan uap airnya akan semakin rendah. Nilai WVTR pada edible film minyak atsiri jeruk purut sebesar 0,291-0,857 g/jam m².

Barus (2002) dalam Windari et al. (2014), menyatakan bahwa perpindahan uap air terjadi pada bagian hidrofilik film. Senyawa terpena yang terkandung dalam minyak atsiri kemangi mampu meningkatkan sifat hidrofobik edible film yang menyebabkan film sulit dilalui oleh uap air (Putra et al., 2017). Selain itu, nilai WVTR ini berkaitan dengan ketebalan film. Penambahan minyak atsiri menyebabkan ketebalan film meningkat. Semakin tebal film, film akan bersifat kaku dan keras. Hal ini mengakibatkan film semakin sulit dilalui oleh uap air sehingga laju transmisi uap airnya rendah (Jacoeb et al., 2014). 


\section{Kuat Tarik}

Kuat tarik termasuk sifat mekanik yang penting dalam penentuan karakteristik film. Film yang memiliki nilai kuat tarik tinggi memiliki kemampuan melindungi produk dari kerusakan mekanis dibanding film dengan nilai kuat tarik rendah (Ekariski et al., 2017).

Pengujian kuat tarik sampel edible film minyak atsiri kemangi dilakukan menggunaan alat Zwicki L Z 0,5 universal testing machine. Pada Tabel 4 menunjukkan kuat tarik edible film natrium alginat-minyak atsiri kemangi berkisar antara 2,718-2,788 MPa. Standar kuat tarik berdasarkan JIS (1975) dalam Nurindra et al. (2015), sebesar 0,392 MPa sehingga dapat diketahui bahwa nilai kuat tarik edible film natrium alginat dengan penambahan minyak atsiri kemangi sudah memenuhi standar JIS.

Hasil analisis one way ANOVA $(a=0,05)$ menunjukkan bahwa penggunaan minyak atsiri kemangi dengan konsentrasi $0,5 \%, 1 \%$, dan 1,5\% tidak memberikan nilai kuat tarik yang berbeda secara signifikan. Hal ini diduga minyak atsiri kemangi tidak mampu berikatan secara optimal dengan natrium alginat sehingga ikatan antara polimer dan minyak atsiri kemangi yang terbentuk sedikit.

Hasil penelitian ini berbeda dengan hasil penelitian Sholehah et al. (2016), yang menyatakan penambahan minyak atsiri lengkuas merah mampu meningkatkan kuat tarik pada edible film refined carrageenan. Nilai kuat tarik edible film refined carrageenan dengan penambahan minyak atsiri lengkuas merah berkisar antara 17,98-28,40 MPa.

\section{Penentuan Konsentrasi Terpilih}

Beberapa konsentrasi terpilih yang dapat dianalisis pada penelitian ini dimaksudkan agar dapat mengidentifikasi kandungan mana yang menjadi pemicu penghambatan pertumbuhan bakteri sehingga dapat meningkatkan umur simpan ikan nila pada hasil akhirnya. Tabel 2 menunjukkan minyak atsiri kemangi konsentrasi 1,5\% termasuk dalam kategori sedang karena memiliki diameter hambat antara 16-28 mm. Berdasarkan hasil tersebut dapat diketahui bahwa penggunaan minyak atsiri kemangi 1,5\% diduga lebih efektif dalam menghambat pertumbuhan bakteri.

Edible film yang baik menurut JIS (1975) dalam Nurindra et al. (2015) adalah film yang memiliki ketebalan dibawah 0,25 mm. Pada Tabel 3, edible film dengan penambahan be- berapa konsentrasi minyak atsiri kemangi masih memenuhi standar JIS. Ghanbarzadeh et al. (2011), menyatakan bahwa film yang digunakan untuk mengemas produk pangan harus memiliki laju transmisi uap air serendah mungkin agar mampu menjaga kualitas dari produk pangan tersebut. Berdasarkan pernyataan tersebut, edible film dengan penambahan minyak atsiri kemangi konsentrasi $1 \%$ dan 1,5\% diduga mampu melindungi produk pangan dari kerusakan yang lebih baik dibandingkan dengan edible film dengan penambahan minyak atsiri 0,5\%. Hasil uji kuat tarik (Tabel 3) menunjukkan penambahan minyak atsiri kemangi dengan beberapa konsentrasi yang berbeda tidak menunjukkan perbedaan yang signifikan, sehingga memiliki kemampuan yang sama dalam melindungi produk dari kerusakan mekanis.

Berdasarkan Tabel 2 dan Tabel 3, dapat diketahui bahwa penambahan minyak atsiri kemangi dengan konsentrasi 1,5\% memiliki aktivitas yang lebih baik dan mampu menghasilkan edible film dengan karakteristik yang lebih baik dibandingkan dengan konsentrasi $0,5 \%$ dan $1 \%$. Oleh karena itu, digunakan konsentrasi minyak atsiri kemangi $1,5 \%$ untuk tahap aplikasi edible coating minyak atsiri kemangi pada fillet ikan nila.

\section{Aplikasi Edible Coating Berbasis Natrium Alginat dengan Penambahan Minyak Atsiri Kemangi Pada Fillet Ikan Nila \\ Thiobarbituric Acid (TBA)}

Penggunaan natrium alginate yang diaplikasikan sebagai edible coating mampu menghambat laju pertumbuhan mikroba perusak. Hal ini didukung dengan penambahan minyak atsiri sehingga terjadi proses blocking growth yang optimum. Pada Gambar 2 menunjukkan fillet ikan nila dengan perlakuan kontrol memiliki nilai TBA yang lebih tinggi dibandingkan dengan sampel dengan penambahan minyak atsiri kemangi 1,5\%. Uji paired t-test $(a=0,05)$ menunjukkan bahwa penggunaan edible coating dengan perlakuan kontrol dan minyak atsiri kemangi 1,5\% memberikan perbedaan yang signifikan terhadap nilai TBA fillet ikan nila. Berdasarkan hasil uji one way ANOVA dengan $a=0,05$ dapat diketahui bahwa sampel dengan perlakuan kontrol maupun dengan edible coating minyak atsiri kemangi 1,5\% mengalami peningkatan yang signifikan selama 12 hari penyimpanan. Pada sampel dengan perlakuan kontrol, nilai 
Jurnal Teknologi Pertanian Vol. 21 No. 3 [Desember 2020] 175-190

Edible Coating Minyak Atsiri Kemangi (Ocimum Basilicum) Pada Fillet Ikan Nila [Agustin dkk]

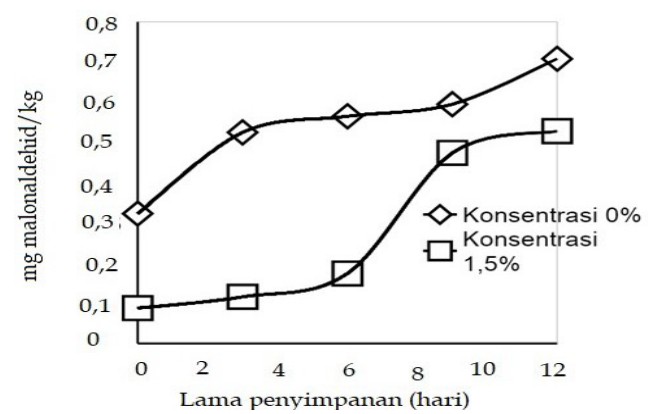

Gambar 2. Pengaruh penggunaan edible coating minyak atsiri kemangi terhadap nilai TBA fillet ikan nila

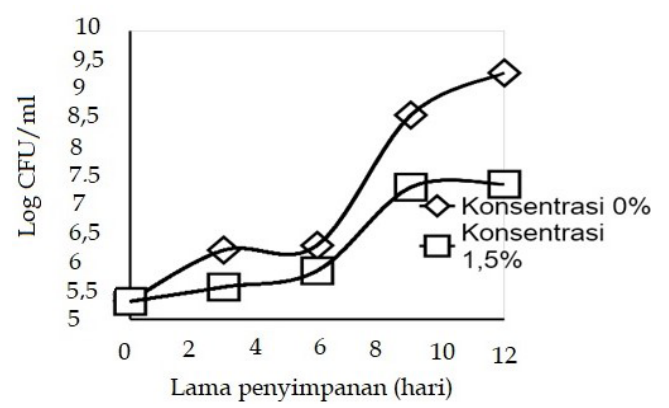

Gambar 3. Pengaruh penggunaan edible coating minyak atsiri kemangi terhadap nilai TPC fillet ikan nila

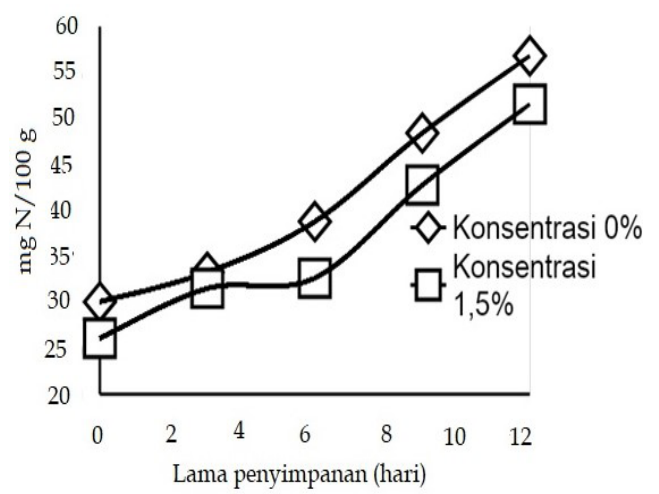

Gambar 4. Pengaruh penggunaan edible coating minyak atsiri kemangi terhadap nilai TVB fillet ikan nila

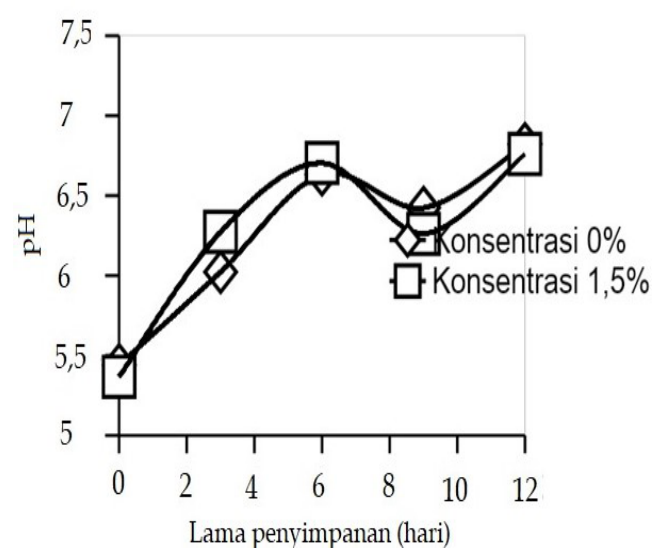

Gambar 5. Pengaruh penggunaan edible coating minyak atsiri kemangi terhadap $\mathrm{pH}$ fillet ikan nila 
TBA mulai meningkat secara signifikan pada hari ke-3, sedangkan pada sampel dengan penambahan minyak atsiri kemangi 1,5\% nila TBA mulai meningkat secara signifikan pada hari ke-6.

Nilai TBA pada sampel dengan perlakuan kontrol meningkat dari 0,323 $\mathrm{mg}$ malonaldehid/kg menjadi $0,708 \mathrm{mg}$ malonaldehid $/ \mathrm{kg}$. Pada sampel dengan penambahan minyak atsiri kemangi 1,5\% nilai TBA meningkat dari $0,088 \mathrm{mg}$ malonaldehid/ $\mathrm{kg}$ menjadi 0,528 mg malonaldehid/ kg. Utami et al. (2013) menyatakan bahwa ikan mulai tidak layak dikonsumsi apabila nilai TBA sudah mencapai 1-2 mg malonaldehid $/ \mathrm{kg}$, sehingga dapat diketahui fillet ikan nila masih layak dikonsumsi sampai hari ke-12 baik pada perlakuan kontrol maupun penambahan minyak atsiri kemangi $1,5 \%$.

Pada sampel dengan perlakuan edible coating minyak atsiri kemangi 1,5\% memiliki nilai TBA yang lebih rendah dikarenakan adanya senyawa antioksidan pada minyak atsiri kemangi. Antioksidan merupakan senyawa yang dapat mengganggu reaksi rantai radikal bebas seperti dalam reaksi oksidasi lipida. Antioksidan akan bereaksi dengan radikal asam lemak setelah senyawa tersebut terbentuk (Yuslianti, 2018). Minyak atsiri kemangi yang dihasilkan mengandung beberapa senyawa antioksidan seperti a-terpineol (Khaleel et al., 2018), nerol (Marques et al., 2013), Trans-a-bergamotene (Poonkodi, 2016), $\beta$-bisabolene, cis- $\alpha$-bisabolene, dan caryophyllene oxide (Okoh et al., 2011).

\section{Total Plate Count (TPC)}

Ikan memiliki kandungan air dan protein yang tinggi. Hal tersebut menyebabkan ikan menjadi media yang baik bagi pertumbuhan mikroba. Mikroba yang terdapat pada permukaan tubuh ikan akan masuk ke dalam tubuh ikan sehingga menyebabkan kebusukan. Untuk mengetahui cemaran mikroba dan kelayakan fillet untuk dikonsumsi, maka dilakukan pengujian Total Plate Count (TPC).

Gambar 3 menunjukkan jumlah mikroba meningkat seiring dengan bertambahnya waktu penyimpanan. Jumlah mikroba pada sampel dengan perlakuan kontrol lebih tinggi dibandingkan dengan sampel dengan penambahan minyak atsiri kemangi 1,5\%. Hasil uji paired $t$-test pada hari ke- 0 menunjukkan tidak terdapat perbedaan yang signifikan antara penggunaan edible coating perlakuan kontrol dan penambahan minyak atsiri $1,5 \%$ terhadap nilai TPC fillet ikan nila, sedangkan pada hari ke-3, 6, 9, 12 penggunaan minyak atsiri kemangi 1,5\% memberikan perbedaan nyata terhadap jumlah mikroba pada fillet ikan nila.

Berdasarkan analisis one way ANOVA dengan $a=0,05$ dapat diketahui bahwa sampel dengan perlakuan kontrol mengalami peningkatan jumlah mikroba yang signifikan pada hari ke-3,6,9, dan 12, sedangkan pada sampel dengan penambahan minyak atsiri kemangi 1,5\% baru mengalami peningkatan jumlah mikroba yang signifikan pada hari ke-9.

Batas maksimum cemaran mikroba pada fillet ikan berdasarkan SNI 2696:2013 adalah 5,0x $10^{5}$ atau 5,69 log CFU/ml sampel. Jumlah mikroba pada sampel fillet ikan nila dengan perlakuan kontrol sudah melebihi batas maksimum cemaran mikroba pada hari ke-3, sedangkan jumlah mikroba sampel fillet ikan nila dengan penambahan minyak atsiri kemangi 1,5\% sudah melebihi batas maksimum cemaran mikroba pada hari ke-6.

Jumlah mikroba pada sampel dengan perlakuan kontrol lebih tinggi dibandingkan dengan sampel dengan penambahan minyak atsiri kemangi 1,5\%. Pada perlakuan kontrol, jumlah mikroba meningkat sebesar 3,95 log $\mathrm{CFU} / \mathrm{ml}$, sedangkan pada perlakuan minyak atsiri kemangi 1,5\% meningkat sebesar 2,03 $\log \mathrm{CFU} / \mathrm{ml}$. Berdasarkan data tersebut, dapat diketahui bahwa edible coating dengan penambahan minyak atsiri kemangi 1,5\% lebih efektif dalam mencegah pertumbuhan mikroba pada fillet ikan nila dibandingkan dengan edible coating perlakuan kontrol. Pada minyak atsiri kemangi, terdapat beberapa senyawa terpena yang berperan sebagai antimikroba, sehingga dengan adanya senyawa antimikroba tersebut mampu menghambat pertumbuhan mikroba pada fillet ikan nila.

\section{Total Volatile Base (TVB)}

Penentuan tingkat kesegaran ikan secara kimiawi dapat dilakukan dengan penetapan Total Volatile Base (TVB). Prinsip penentapan TVB dengan cara menguapkan senyawa-senyawa yang terbentuk akibat penguraian asam amino yang terdapat pada daging ikan (Nurjanah et al., 2011)

Gambar 4 menunjukkan nilai TVB sampel dengan penambahan minyak atsiri kemangi 1,5\% lebih rendah dibandingkan dengan sampel dengan perlakuan kontrol. Berdasarkan uji paired $t$-test $(\alpha=0,05)$, pada hari ke-9 dan 12 tidak terdapat perbedaan 
nilai TVB yang signifikan pada konsentrasi kontrol dan minyak atsiri kemangi 1,5\%. Melalui uji one way ANOVA $(a=0,05)$ dapat diketahui sampel dengan perlakuan kontrol dan penambahan minyak atsiri kemangi 1,5\% mengalami peningkatan nilai TVB yang signifikan selama 12 hari penyimpanan. Nilai TVB sampel kontrol meningkat sebesar 26,775 mg N/100 g, sedangkan pada sampel dengan penambahan minyak atsiri kemangi $1,5 \%$ meningkat sebesar 25,471 mg N/100 g. Berdasarkan data tersebut dapat diketahui bahwa penggunaan edible coating minyak atsiri $1,5 \%$ lebih efektif dalam mempertahankan nilai TVB.

Ozyurt et al. (2009) menyatakan bahwa batas penerimaan terhadap nilai TVB pada produk perikanan sebesar 30-35 mg N/100 g. Berdasarkan hal tersebut dapat diketahui bahwa nilai TVB sampel kontrol sudah melebihi batas penerimaan pada hari ke-6, sedangkan untuk sampel dengan perlakuan edible coating minyak atsiri kemangi 1,5\% sudah melebihi batas penerimaan pada hari ke-9.

Peningkatan nilai TVB disebabkan adanya penguraian protein dalam ikan nila oleh enzim proteolitik yang memutuskan protein menjadi ikatan peptida yang pendek dan asam amino yang kemudian menjadi senyawa amin dan ammonia yang berbau busuk. Enzim yang berperan dalam penguraian protein dihasilkan dari aktivitas bakteri (Farahita et al., 2012).

Berdasarkan Apriani et al. (2017), peningkatan jumlah bakteri dipengaruhi oleh proses autolisis. Autolisis merupakan proses penguraian organ tubuh ikan oleh enzim yang terdapat dalam ikan tersebut. Hasil penguraian enzim merupakan media yang cocok untuk pertumbuhan bakteri dan mikroba lain. Pada sampel kontrol tidak terdapat senyawa antimikroba seperti pada sampel dengan penambahan minyak atsiri kemangi 1,5\%. Pertumbuhan bakteri akan terhambat dengan adanya senyawa antimikroba. Terhambatnya pertumbuhan bakteri dapat menyebabkan produksi enzim hasil aktivitas bakteri menurun yang mengakibatkan proses pemecahan protein lebih lambat. Nilai TVB saling berhubungan dengan nilai $\mathrm{pH}$. Protein yang dirombak oleh enzim akan menghasilkan ammonia dan senyawa volatil lainnya yang bersifat basa. Semakin tinggi nilai TVB maka $\mathrm{pH}$ ikan akan semakin basa (Al-Hakim et al., 2016)

\section{Derajat Keasaman (pH)}

Nilai pH merupakan indikator yang digunakan untuk menentukan kesegaran ikan. Perubahan $\mathrm{pH}$ pada ikan berperan besar dalam proses autolisis dan penyerangan bakteri (Munandar et al., 2009). Gambar 5 menunjukkan $\mathrm{pH}$ ikan naik pada hari ke-3 dan ke-6. $\mathrm{pH}$ fillet ikan nila pada perlakuan kontrol mengalami kenaikan sebesar 1,382, sedangkan pada perlakuan minyak atsiri $1,5 \%$ meningkat sebesar 1,393. Peningkatan $\mathrm{pH}$ merupakan indikator mikroba dapat beradaptasi dengan lingkungan (Al-Hakim et al., 2016).

Uji paired t-test $(\alpha=0,05)$, menunjukkan tidak ada perbedaan nyata antara perlakuan kontrol dan minyak atsiri 1,5\% terhadap $\mathrm{pH}$ fillet ikan nila sejak hari ke-0 sampai hari ke12. Berdasarkan hasil analisis one way ANOVA $(a=0,05)$, dapat diketahui bahwa nilai $\mathrm{pH}$ meningkat secara signifikan baik pada sampel kontrol maupun sampel dengan penambahan minyak atsiri kemangi 1,5\%.

$\mathrm{pH}$ mengalami peningkatan akibat perombakan protein oleh enzim proteolitik (autolisis). Pemanfaatan ATP untuk menghambat penurunan kesegaran akan menghasilkan senyawa ammonia yang bersifat basa. Proses autolisis diikuti dengan peningkatan jumlah bakteri, sebab hasil penguraian enzim selama autolisis merupakan media yang cocok untuk pertumbuhan mikroba (Liviawaty dan Afrianto, 2014). Akan tetapi, pH ikan kembali menurun pada hari ke-9 dan meningkat pada hari ke-12. Penurunan $\mathrm{pH}$ tersebut diduga terjadinya akibat akumulasi asam yang dihasilkan oleh bakteri asidogenik (penghasil asam) yang terdapat pada fillet ikan nila. Bakteri asidogenik merubah monomer hasil tahap hidrolisis seperti gula, asam lemak, dan asam amino menjadi asam-asam organik, keton, $\mathrm{CO}_{2}$, dan $\mathrm{H}_{2}$. Contoh bakteri asidogenik antara lain Clostridium, Lactobacillus, Pseudomonas, Bacillus, dan Escherichia (Witari dan Nurika, 2016).

$\mathrm{pH}$ ikan segar berkisar antara 6,8-7, ikan dengan $\mathrm{pH}$ 2-6,5 berarti telah memasuki fase rigor mortis, sedangkan ikan yang telah busuk memiliki nilai $\mathrm{pH}$ tinggi berkisar antara 8-10 (Waluyo dan Kusuma, 2017). Hal tersebut menunjukkan sampel dengan penggunaan edible coating kontrol dan minyak atsiri kemangi 1,5\% telah memasuki fase rigor mortis sejak awal penyimpanan akan tetapi belum mengalami kebusukan sampai 12 hari penyimpanan suhu dingin. 


\section{SIMPULAN}

Berdasarkan penelitian yang telah dilakukan, dapat disimpulkan bahwa minyak atsiri kemangi hasil destilasi memiliki rendemen sebesar $0,40 \%$, berat jenis $0,8533 \mathrm{~g} / \mathrm{cm}^{3}$, viskositas $0,0020 \mathrm{~N} . \mathrm{s} / \mathrm{m}^{2}$, dan pada konsentrasi $1,5 \%$ dapat dikategorikan sebagai antimikroba dengan daya hambat tinggi dengan diameter hambat sebesar $18,35 \mathrm{~mm}$. Penambahan minyak atsiri kemangi dalam edible film natrium alginat tidak berpengaruh secara sigifikan pada parameter kuat tarik akan namun masih memiliki kemampuan meningkatkan ketebalan edible film dan menurunkan nilai WVTR sebesar $0,869 \mathrm{~g} / \mathrm{jam} . \mathrm{m}^{2}$. Penggunaan edible coating dengan penambahan minyak atsiri kemangi 1,5\% melebihi batas penerimaan konsumen pada hari ke-9 sedangkan pada perlakuan kontrol sudah melebihi batas penerimaan pada hari ke-6 berdasarkan parameter TVB.

\section{DAFTAR PUSTAKA}

Al-Hakim, M, -L., Hartanto, -R., Nurhartadi, -E., 2016. Pengaruh penggunaan asam asetat dan edible coating ekstrak bawang putih terhadap kualitas fillet ikan nila merah (Oreochromis niloticus) selama penyimpanan suhu dingin. Jurnal Teknologi Hasil Pertanian, 9(1), 24-33. https:/ / doi. org/10.20961/jthp.v9i2.12850

Al-Maskri, A, -Y., Hanif, M, -A., Al-Maskari, M, -Y., Abraham, A, -S., Al-sabahi, J, -N., Al-Mantheri, -O., 2011. Essential oil from Ocimum basilicum (Omani basil): A desert crop. Natural Product Communications. 6(10), 1487-1490. https:// doi.org/10.1177\%2F193457 8X1100601020

Apriani, -D., Gusnedi., Darvina, -Y., 2013. Studi tentang nilai viskositas madu hutan dari beberapa daerah di Sumatera Barat untuk mengetahui kualitas madu. Phillar of Physics. 2, 91-98. http:/ / ejournal.unp.ac.id/students/ index.php/fis/article/view/758/515

Apriani, -R., Ferasyi, T, -R., Razali., 2017. Jumlah cemaran mikroba dan nilai organoleptik ikan tongkol (Euthynnus affinis). Jurnal Ilmiah Mahasiswa Veteriner. 1(3), 598-603. https://doi.org/10.21157/ jim\%20vet..v1i3.4223
Arham, -R., Mulyati, M, -T., Metusalach, -M., Salengke, -S., 2016. Physical and mechanical properties of agar based edible film with glycerol plasticizer. International Food Research Journal. 23(4), 1669-1675. http://www.ifrj.upm.edu. my $/ 23 \% 20(04) \% 202016 /(42)$.pdf

Boziaris, IS., Parlapani, FF. 2017. 'Specific Spoilage Organisms (SSOs) in Fish'. Dalam A Bevilacqua, MR Corbo, M Sinigaglia (ed). The Microbiological Quality of Food. Woodhead Publishing

Chakraborty, -R., Dey, -T., 2016. Drying protocols for traditional medicinal herbs: A critical review. International Journal of Engineering Technology, Management, and Applied Sciences. 4(4), 312-319. http://www.ijetmas.com/ admin/resources/project/paper/ f201605021462181254.pdf

Chenni, -M., El Abed, -D., Rakotomanomana, -N., Fernandez, -X., Chemat, -F., 2016. Comparative study of essential oils extracted from egyptian basil leaves (Ocimum basilicum 1.) using hydro-distillation and solvent-free microwave extraction. Molecules. 21(1), 1-16. https://doi.org/10.3390/molecules 21010113

Dahham, S, -S., Tabana, Y, -M., Iqbal, M, -A., Ahamed, M, B, -K., Ezzat, M, -O., Majid, S. A, -M., Majid, A, M, S, -A., 2015. The anticancer, antioxidant and antimicrobial properties of the sesquiterpene $\beta$-caryophyllene from the essential oil of Aquilaria crassna. Molecules. 20(7), 11808-11829. https://doi. org/10.3390/molecules200711808

Ekariski, -D., Basito., Yudhistira, -B., 2017. Studi karakteristik fisik dan mekanik edible film pati ubi jalar ungu dengan penambahan kitosan. Jurnal Teknologi Hasil Pertanian. 10(2), 128-134. https:/ / doi.org/10.20961/jthp.v10i2.29080

Elgayyar, -M., Draughon, F, -A., Golden, D, -A., Mount, J, R., 2001. Antimicrobial activity of essential oils from plants against selected pathogenic and saprophytic microorganisms. Journal of Food Protection. 64(7), 1019-1024. https:// doi.org/10.4315/0362-028X-64.7.1019

Fajarini, D, -A., Murrukmihadi, -M., 2015. Repellent activity test of essential oil of basil leaves (Ocimum basilicum (L.) f. Citratum Back) against Aedes Aegypti lotion and physical character- 
istics test of the lotion. Majalah Obat Tradisional. 20(2), 96-102. https:/ / doi. org/10.22146/tradmedj.8078

Farahita, -Y., Junianto., Kurniawati, -N., 2012. Karakteristik kimia caviar nilem dalam perendaman campuran larutan asam asetat dengan larutan garam selama penyimpanan suhu dingin (5-10 ${ }^{\circ}$ )). Jurnal Perikanan dan Kelautan. 3(4), 165-170. http://jurnal.unpad.ac.id/ jpk/article/view/2558/2316

Ghanbarzadeh, -B., Almasi, -H., Entezami, A, -A., 2011. Improving the barrier and mechanical properties of corn starch-based edible films: Effect of citric acid and carboxymethyl cellulose. Industrial Crops and Products. 33(1), 229-235. https://doi.org/10.1016/j. indcrop.2010.10.016

Gustiano, -R., Arifin, O, -Z., Nugroho, -E., 2008. Perbaikan pertumbuhan ikan nila (Oreochromis niloticus) dengan seleksi famili. Media Akuakultur. 3(2), 98-106. http://dx.doi.org/10.15578/ ma.3.2.2008.98-106

Hassanpouraghdam, M, -B., Hassani, -A., Vojodi, -L., Farsad-Akhtar, -N., 2010. Drying method affects essential oil content and composition of basil (Ocimum basilicum L.). Journal of Essential Oil-Bearing Plants. 13(6), 759-766. https://doi. org/10.1080/0972060X.2010.10643892

Husni, A., Putra, MP. 2018. Pengendalian Mutu Hasil Perikanan. UGM Press

Jacoeb, A, -M., Nugraha, -R., Utari, S, P, S, -D., 2014. Pembuatan edible film dari pati buah lindur dengan penambahan gliserol dan karaginan. Jurnal Pengolahan Hasil Perikanan Indonesia. 17(1), 14-21. https://doi.org/10.17844/jphpi.v17i1.8132

JIS. (1975). Japanese Industrial Standard 2 1707. Japanese Standards Association.

Khasanah, L, -U., Kawiji, Utami, -R., Aji, Y, M., 2015. Pengaruh perlakuan pendahuluan terhadap karakteristik mutu minyak atsiri daun jeruk purut (Citrus hystrix DC). Jurnal Aplikasi Teknologi Pangan. 4(2), 48-55. http://www. jatp.ift.or.id/index.php/jatp/article/ view /98

Khaleel, -C., Tabanca, -N., Buchbauer, -G., 2018. a-Terpineol, a natural monoterpene: A review of its biological properties. Open Chemistry. 16(1), 349-361. https://doi.org/10.1515/chem-2018-
0040

Kusumawati, D, -H., Putri, W, D, -R., 2013. Karakteristik fisik dan kimia edible film pati jagung yang diinkorporasi dengan perasan temu hitam. Jurnal Pangan dan Agroindustri. 1(1), 90-100. https://jpa.ub.ac.id/index.php/jpa/ article/view/9

Ladwani, A, M, -A., Salman, -M., Abdel Hameed, -ES., 2018. Chemical composition of Ocimum basilicum L. essential oil from different regions in the Kingdom of Saudi Arabia by using Gas chromatography mass spectrometer. Journal of Medicinal Plants Studies. 6(1), 14-19. https://www.plantsjournal.com/arch ives $/$ ? year $=2018 \&$ vol $=6 \&$ issue $=1 \&$ pa $\mathrm{rt}=\mathrm{A} \&$ ArticleId $=740$

Legault, -J., Simard, -S., Pichette, -A., Cote, P, -A., Oullet, -S., 2013. Iso-caryophyllene cytotoxicity induced by lipid peroxidation and membrane permeabilization in L-929 cells. Journal of Applied Pharmaceutical Science. 3(8), 25-31. http:// dx.doi.org/ 10.7324/JAPS.2013.3805

Linde, J, -H., Combrinck, -S., Regnier, T, J, -C., Virijevic, -S., 2010. Chemical composition and antifungal activity of the essential oils of Lippia rehmannii from South Africa. South African Journal of Botany. 76(1), 37-42. https://doi. org/10.1016/j.sajb.2009.06.011

Lingga, A, -R., Pato, -U., Rossi, -E., 2016. Uji antibakteri ekstrak batang kecombrang (Nicolaia speciosa Horan) terhadap Staphylococcus aureus dan Eschericia coli. Jurnal Online Mahasiswa Fakultas Pertanian Universitas Riau. 3(1), 99-102. https://jom.unri.ac.id/ index.php/JOMFAPERTA/article/ view $/ 9580$

Liviawaty, -E., Afrianto, -E., 2014. Penentuan waktu rigor mortis ikan nila merah (Oreochromis Niloticus) berdasarkan pola perubahan derajat keasaman. Jurnal Akuatika Indonesia. 5(1), 40-44. http://jurnal.unpad.ac.id/akuatika/ article/view/3703/2426

Lu, -F., Liu, -D., Ye, -X., Wei, -Y., Liu, -F., 2009. Alginate-calcium coating incorporating nisin and EDTA maintains the quality of fresh northern snakehead (Channa argus) fillets stored at 4 ${ }^{\circ} \mathrm{C}$. Journal of the Science of Food and Agriculture. 89(5), 848-854. https://doi. org/10.1002/jsfa.3523 
Marques, T, H, -C., Marques, M, L, B, G, C, -B., Lima, D, -dos S., Siqueira, H, D, -S., Neto, J, D, -N., Branco, M, do S, -B. G. C., Souza, A. A. de, Sousa, D. P. de, \& Freitas, R. M. de. (2013). Evaluation of the neuropharmacological properties of nerol in mice. World Journal of Neuroscience, 3, 32-38. http://dx.doi. org/10.4236/wjns.2013.31004

Mindaryani, -A., Rahayu, S, -S., 2007. Essential oil from extraction and steam distillation of Ocimum Basillicum. Proceeding of the World Congress on Engineering and Computer Science, San Franscisco, USA, pp. 90-94

Mokarizadeh, -M., Kafil, H, -S., Ghanbarzadeh, -S., Alizadeh, -A., Hamishehkar, -H., 2017. Improvement of citral antimicrobial activity by incorporation into nanostructured lipid carriers: A potential application in food stuffs as a natural preservative. Research in Pharmaceutical Sciences. 12(5), 409415. https://doi.org/10.4103/17355362.213986

Munandar, A, Nurjanah, Nurilmala, M. 2009. Kemunduran Mutu Ikan Nila (Oreochromis niloticus) pada Penyimpanan Suhu Rendah dengan Perlakuan Cara Kematian dan Penyiangan. Skripsi. IPB. Bogor

Nura, -A., Chukwuma, A, -C., Oneh, A, -J., 2016. Critical review on principles and application of hurdle technology in food preservation. Annals. Food Science and Technology. 17(2), 485-491. http:// www.afst.valahia.ro/images/documente/2016/issue2/full/w29_full. pdf

Nugraheni, K, -S., Khasanah, L, -U., Utami, -R., Ananditho, B, -K., 2016. Pengaruh perlakuan pendahuluan dan variasi metode destilasi terhadap karakteristik mutu minyak atsiri daun kayu manis (C. Burmanii). Jurnal Teknologi Hasil Pertanian. 9(2), 51-64. https:// doi.org/10.20961/jthp.v9i2.17466

Nurindra, A, -P., Alamsjah, M, -A., Sudarno., 2015. Karakterisasi edible film dari pati propagul mangrove lindur (Bruguiera Gymnorrhiza) dengan penambahan Carboxymethyl Cellulose (Cmc) sebagai pemlastis. Jurnal
Ilmiah Perikanan dan Kelautan. 7(2), 10-17. http://dx.doi.org/10.20473/ jipk.v7i2.11195

Nurjanah, Nurhayati, -T., Zakaria, -R., (2011). Kemunduran mutu ikan gurami (Osphronemus gouramy) pasca kematian pada penyimpanan suhu chilling. Akuatik-Jurnal Sumberdaya Perairan. 5(2), 11-18. https://journal.ubb. ac.id/index.php/akuatik/article/ view $/ 450 / 403$

Okoh, S, -O., Asekun, O, -T., Familoni, O, -B., Afolayan, A, -J., 2011. Composition and antioxidant activities of leaf and root volatile oils of Morinda lucida. Natural Product Communications. 6(10), 1537-1541. https://doi.org/10.1177\% 2F1934578X1100601032

Özyurt, -G., Kuley, -E., Özkütük, -S., Özogul, -F., 2009. Sensory, microbiological and chemical assessment of the freshness of red mullet (Mullus barbatus) and goldband goatfish (Upeneus moluccensis) during storage in ice. Food Chemistry. 114(2), 505-510. https://doi. org/10.1016/j.foodchem.2008.09.078

Parreidt, T, -S., Müller, -K., Schmid, -M., 2018. Alginate-based edible films and coatings for food packaging applications. Foods. 7(10), 1-38. https://dx.doi. org/10.3390\%2Ffoods7100170

Perikanan, KK. 2018. Peta Sentra Produksi Perikanan Budidaya.

Politeo, -O., Jukic, -M., Milos, -M., 2007. Chemical composition and antioxidant capacity of free volatile aglycones from basil (Ocimum basilicum L.) compared with its essential oil. Food Chemistry. 101(1), 379-385. https://doi. org/10.1016/j.foodchem.2006.01.045

Poonkodi, -K., 2016. Chemical composition of essential oil of Ocimum basilicumL. (Basil) and its biological activities-an overview. Journal of Critical Reviews. 3(3), 56-62. https://www.bibliomed. org/mnsfulltext/197/197-1572429367. pdf?1607849979

Pujiarti, -R., Widowati, T, -B., Kasmudjo., Sunarta, -S., 2015. Kualitas, komposisi kimia, dan aktivitas antioksidan minyak kenanga (Cananga odorata). Jurnal Ilmu Kehutanan. 9(1), 3-11. https:// doi.org/10.22146/jik.10179 
Putra, A, S, -P., Ali, -A., Efendi, -R. 2017. Karakteristik edible film pati tapioka dengan penambahan minyak atsiri daun jeruk purut sebagai antibakteri. Sagu, Agricultural Science and Technology Journal. 16(1), 13-20. https://sagu. ejournal.unri.ac.id/index.php/JSG/ article/view/5397/0

Rosida, DF, Hapsari, N, Dewati, R. 2018. Edible Coating dan Film dari Biopolimer Bahan Alami Terbarukan. Penerbit Uwais, Ponorogo

Sahubawa, L, Ustadi. 2014. Teknologi Pengawetan dan Pengolahan Hasil Perikanan. UGM Press, Yogyakarta

Setyaningrum, -A., Sumarni, N, -K., Hardi, -J., 2017. Sifat fisiko-kimia edible film agar-agar rumput laut (Gracilaria sp.) tersubtitusi glyserol. Natural Science: Journal of Science and Technology. 6(2), 136-143. http://jurnal.untad.ac.id/ jurnal/index.php/ejurnalfmipa/article/view/8661

Shabanpour, -B., Chamanara, -V., Khomeiri, -M., Gorgin, -S., 2013. Shelf-life extension of fish samples by using enriched chitosan coating with thyme essential oil. Journal of Aquatic Food Product Technology. 22(1), 3-10. https://doi.org/10 $.1080 / 10498850.2011 .621583$

Sholehah, M, -M., Ma'aruf, W, -F., Romadhon. 2016. Karakteristik dan aktivitas antibakteri edible film dari refined carageenan dengan penambahan minyak atsiri lengkuas merah (Alpinia purpurata). Jurnal Pengolahan dan Bioteknologi Hasil Perikanan. 5(3), 2-9. https:// ejournal3.undip.ac.id/index.php/ jpbhp/article/view/16009

Sipayung, B, -S., Ma'ruf, W, -F., Dewi, E, -N., 2015. Pengaruh senyawa bioaktif buah mangrove Avicennia Marina terhadap tingkat oksidasi fillet ikan nila merah O. Niloticus selama penyimpanan dingin. Jurnal Pengolahan dan Bioteknologi Hasil Perikanan. 4(2), 115-123. https:// ejournal3.undip.ac.id/index.php/ jpbhp/article/view/9201

Slamet., Ulyarti., Rahmi, S, -L., 2019. Pengaruh lama fermentasi terhadap rendemen dan mutu fisik minyak nilam (Pogostemon cablin Benth). Jurnal Teknologi dan Industri Pertanian Indonesia. 11(1),
19-25. https://doi.org/10.17969/jtipi. v11i1.11671

Srivastava, H, -C., Shukla, -P., Tripati, -S., Shanker, -B., 2014. Antioxidant and antimicrobial activities of sweet basil oils. International Journal of Pharmaceutical Sciences and Research. 5(2), 279-285. http://dx.doi.org/10.13040/ IJPSR.0975-8232.5(1).279-85

Swamy, M, -K., Akhtar, M, -S., Sinniah, U, -R., 2016. Antimicrobial properties of plant essential oils against human pathogens and their mode of action: An updated review. Evidence-Based Complementary and Alternative Medicine. 2016, 1-21. https://doi.org/10.1155/2016/3012462

Utami, -R., Kawiji., Nurhartadi, -E., Kurniasih, -M., Indianto, -D., 2013. Pengaruh minyak atsiri jahe merah dan lengkuas merah pada edible coating terhadap kualitas fillet ikan patin. 33(4), 399-406. https://doi.org/10.22146/ agritech.9535

Vital, A, C, -P., Guerrero, -A., Ornaghi, M, -G., Kempinski, E, M, B, -C., Sary, -C., Monteschio, J, -O., Matumoto-Pintro, P, -T., Ribeiro, R, -P., do Prado, I, -N., 2018. Quality and sensory acceptability of fish fillet (Oreochromis niloticus) with alginate-based coating containing essential oils. Journal of Food Science and Technology. 55(12), 4945-4955. https:// doi.org/10.1007/s13197-018-3429-y

Waluyo, E, Kusuma, B. 2017. Keamanan Pangan Produk Perikanan. UB Press. Malang

Widati, R, -R., Suranto., Pangastuti, -A., 2006. The effect of Ocimum basilicum L. essential oils toward quality of Oreochromis niloticus fillet in the cold storage. Biofarmasi, Journal of Natural Product Biochemistry. 4(1), 22-26. https://doi. org/10.13057/biofar/f040105

Windari, H, A, -S., Sutrisno, Roosdiana, -A., 2014. Penentuan waktu fermentasi optimum produksi xilanase dari Trichoderma viride menggunakan substrat kulit kedelai dan kulit kacang hijau melalui fermentasi semi padat. Jurnal Ilmu Kimia Universitas Brawijaya. 1(1), 85-91. http://kimia.studentjournal. ub.ac.id/index.php/jikub/article/ view/399 
Jurnal Teknologi Pertanian Vol. 21 No. 3 [Desember 2020] 175-190

Edible Coating Minyak Atsiri Kemangi (Ocimum Basilicum) Pada Fillet Ikan Nila [Agustin dkk]

Witari, A, -S., Nurika, I., 2016. Penentuan isolat bakteri asidogenik yang mampu menghasilkan total asam tertinggi dari limbah cair tahu. Industria : Jurnal Teknologi dan Manajemen Agroindustri,
5(1), 9-20. https://doi.org/10.21776/ ub.industria.2016.005.01.2

Yuslianti, ER. 2018. Pengantar Radikal Bebas dan Antioksidan. Deepublish, Yogyakarta 